\title{
LA METÁFORA PLATÓNICA DEL RETORNO (REDITIO)
}

\author{
Carlos Baliñas Fernández \\ Universidad de Santiago de Compostela
}

\section{RESUMEN}

A la doctrina platónica de la reditio, proseguida por San Agustín, subyace una metáfora de camino. Se trata aquí de analizar el cuadro de sentido donde se inserta el «retorno» y las correspondencias. con otras manifestaciones de la nostalgia de los orígenes.

Palabras clave: metáfora, Plotino, San Agustín.

\begin{abstract}
According to Plato's «reditio» doctrine continued by Saint Agustine underlies a metaphor for the way. It is to analyze where the return is inserted as well as the correspondences of the doctrine with the nostalgia of the origins.
\end{abstract}

Key words: Metaphor, Plotine, Saint Augustine

Los autores de doctrinas «cosmovisionales» están demasiado enfervorizados con presentar y defender su respectiva propuesta como para ocuparse de los compromisos del lenguaje que emplean. Dan por supuesto, como era habitual pensar hasta ahora, que el lenguaje es mero vehículo expresivo. Las doctrinas son asunto del Consciente, que las enuncia, argumenta, defiende, etc. Pero el lenguaje dentro del cual las enuncia le viene dado al pensador y, fuera de cuando se ve obligado a crear algún término técnico, el hablante se expresa sin ser consciente de los condicionamientos, es decir, en situación que llamaré cis-consciente (cis: 'más acá de ${ }^{1}$. Simplemente hace el mejor uso posible de una herramienta que «hay» a disposicion de cualquiera. De la herramienta se fija en su mayor o menor eficacia expresiva, pero no en los compromisos con las maneras de ver la realidad.

Ahora bien, el lenguaje doctrinal es aproximadamente el mismo que el empleado para situaciones y vivencias de la vida cotidiana. Por lo tanto, algún parecido habrá entre esas doctrinas tan «elevadas» y la experiencia de cada dia.

Despreciar el conocimiento de cómo está construida una doctrina equivale a caminar sin tener en cuenta ni el calzado ni el suelo.

Desentendámonos nosotros de opinar acerca de la «verdad» de las doctrinas y estaremos en franquía para estudiar esos condicionantes extradoctrinales.

1 Introduzco esta variante (de Cis, en latín «más acá de», frente a Trans, «más allá») para evitar Subconsciente que, desde Freud, remite a pulsiones 


\section{EL CASO DEL RETORNO AL INTERIOR DE SÍ MISMO}

En el lenguaje diario hablamos de «concentrarse», «mirada interior», «volver» a sí mismo desde la dispersión y la disipación, «interiorizar» un acontecimiento. El psicólogo Jung estableció una tipología según la cual los individuos son extrovertidos o introvertidos. La religiosidad de las religiones no contractuales, las que no se limitan a pactar con la divinidad el do ut des, las religiones de contemplación y pureza de conciencia,consiste en buena parte en retorno a la interioridad desde la disipación en lo mundano: lo que se llama oración, contemplación.

Desde este punto de vista también cabe distinguir dos tipos de filosofía del hombre. La interiorista ve al humano como principalmente conciencia (yo), toma los hechos de conciencia como «datos inmediatos», incita a conocerse a sí mismo (nosce te ipsum) y se propone hacer del individuo persona consciente y responsable ante lo Absoluto (Dios, Razón). Con las diversidades obvias, a este grupo pertenecen el Platón no cosmólogo, las antiguas Escuelas de la Sabiduría, los filósofos religiosos medievales, Spinoza, Nietzsche, Bergson, la fenomenología, los existencialistas y tantos otros.

Por contraposición, las otras serán filosofías exterioristas. Toman al hombre por un ser de la naturaleza y, por lo tanto, naturalmente extrovertido, y a la persona la miran como pieza de un engranaje reductible a número de alguna ley general. En consecuencia esta filosofía exteriorista reserva la dignidad de filosofía para sólo los empirismos, la Filosofía de la Ciencia, la Sociología, la Ideología, y acusará a la otra filosofía, a la de interiorista, de subjetiva y resbaladiza. Además la pondrá en relación desdeñosamente con la religión, con la cual, en efecto, comparte el enfoque interiorista aunque la filosofía lo haga por razonamientos. (Sin embargo, para mentes bastas estas diferencias de matiz pasarán desapercibidas).

Según se advierte, la pareja Interior / Exterior atraviesa toda la rejilla de campos de conocimiento.

Dentro de doctrinas interioristas hay una especialmente enérgica, filosófica, laica en unos autores y religiosa en otros por más que también razonada conceptualmente. Me refiero a la representada por el neoplatónico Plotino y el filósofo religioso San Agustín de Hipona y que podemos denominar del retorno (reditio) al interior (al yo, al alma), dando por supuesto que allí está la verdad (el Absoluto, Dios).

Una doctrina filosófico-metafísica no describe nada emírico verificable, aunque incluye algunos elementos que son datos inmediatos. Por tanto, será en mayor o menor grado construcción de una hipótesis o maqueta metafórica cuya fuerza de convicción vendrá dada por la coherencia del conjunto y la verdad de los datos.

La doctrina del retorno al Absoluto expone un «argumento» o proceso mental y lo hace sobre una metáfora topológica (dentro/fuera) y cinemática (salir/volver) implícita en el texto, pero manifiesta en el vocabulario. Mi propósito es descubrir los compromisos que conlleva esta «construcción» y el vocabulario: todo eso de retorno, extroversión, interiorismo. En efecto, si nos dejamos llevar de la inercia, quien dice u oye expresiones como retorno al sí-mismo desde la disipación, interiorizar y demás, es llevado a pensar únicamente en lo significado por ellas, es decir, en hechos mentales de dirigir la atención, etc. Esos son hechos mentales reales, pero las expresiones empleadas conllevan un compromiso semántico, aparte de lo que mediante ellas se diga, y vale la pena indagar ese compromiso.

\section{HECHOS DE TRES TIPOS}

Pues bien, un análisis de lo que hay oculto tras de esas expresiones detecta hechos de tres tipos.

1) Hechos mentales (psicológicos) de dirección de la atención, que evidentemente son reales y no metafóricos. Concentrar la atención, interiorizar un suceso externo, sentir nostalgia del origen vivenciado como paraíso perdido. 
2) Una metáfora verbal consistente en expresar hechos mentales, inespaciales, valiéndose de vocabulario espacial (interior/exterior, salir/volver, etc.).

3) Derivadamente, probables hechos de tipo gestual somático. En efecto, quien practica esa gimnasia psicológica de vencer la tendencia espontánea a dirigir su atención hacia lo exterior y la tuerce hacia lo interior toma unos ademanes o gestos peculiares: anda con los ojos entornados, cabizbajo, distraído, meditando en silencio. Los monjes, sean cristianos o budistas, pasan horas dedicadas a la meditación, andan con los ojos entornados y como vueltos hacia dentro de sí, etc. Es la virtud que llaman «modestia». Así representan los imagineros, ya desde los iconos bizantinos, a los santos. En tono menor es la virtud del recato que tradicionalmente se pedía a la mujer bajo el nombre de «modestia».

Y un «argumento»: el relato y, en su caso, el programa doctrinal de regreso al origen, a lo primero, dando por obvio que allí espera la felicidad o sea el cese del mal (vivir).

\section{EL VIAJE SIMBÓLICO: LA NOSTALGIA DE LOS ORÍGENES}

Hay ocasiones en que tenemos la impresión de que en la carrera de la vida lo bueno quedó atrás: en lo hogareño, en la tierra natal, en la infancia. («La infancia es la patria del hombre»). En consecuencia quien siente esta impresión intenta regresar a eso, dando por supuesto que allí le espera el goce tranquilo y seguro de lo que anhela.

El poema por antonomasia del retorno es, como todos sabemos, la Odisea, que narra las aventuras, venturas y desventuras que les ocurrieron a los héroes de la Ilíada, de vuelta de la guerra de Troya. A Ulises los dioses valiéndose de los vientos le desvían de su ruta marina hacia Itaca y ha de hacer un largo periplo donde a una sorpresa sucede otra. Cuanto más se dilata el retorno más añora su isla y los suyos: su esposa Penélope, su hijo Telémaco y todas las pequeñeces que la carencia hace grandes: el abuelo Laertes podando sus viñas, el porquerizo Eumeo, el perro Argos y los paisajes familiares. Al fin un día desembarcará en la isla, reconocerá cada cosa como suya, de su pasado (anagnórisis, reconocimiento) y se da por supuesto que allí se quedará a envejecer. Esta nostalgia de la infancia y lo hogareño es un «universal», pero hay pueblos donde se ha cultivado poéticamente este sentimiento» ${ }^{2}$.

Como contraste recuérdese el final de Don Quijote para quien regresar a su aldea significa dejar de ser personaje, reconocerse vencido, ser desposeído, dejar de ser Don Quijote caballero andante y resignarse a ser el labrador Quijano el Bueno. En la historia recordemos la vuelta a casa de Napoleón derrotado en Rusia. Ahora bien, cuando se exhorta a alguien a regresar, esa exhortación trae consigo connotaciones positivas, halagüeñas. Se cuenta con que «en casa», en los orígenes, le espera la satisfacción.

Porque somos educados a separar géneros literarios, no nos percatamos y hasta habrá quien rechace que se relacione con esto la doctrina de los platónicos acerca del retorno hacia el interior. Y, sin embargo, responden a la misma «figura»: la del regreso al origen. Ulises regresa a la tierra natal, al hogar, a la infancia. No importa que Itaca fuese un islote pelado que ahora desilusiona a los turistas» ${ }^{3}$. Es que lo que anhela el nostálgico no es la belleza del paisaje ni la

2 En la poesía gallega y portuguesa se le denomina saudade. En otro lugar puse en paralelo sobre este punto al filósofo Martin Heidegger y la poetisa gallega Rosalía de Castro. Puede verse mi trabajo «A chamada da Terra en Rosalía de Castro e Martin Heidegger», en Actas do I Colóquio luso-galaico sobre a saudade. Viana do Castelo,1996,pp. 135-143.

3 Por lo visto los turistas que van a la isla seducidos por la magia de la Odisea regresan desilusionados y no pueden comprender que ese islote cortado a cantil suscitase tal nostalgia. La propia Odisea dice de la isla ser «apta para cabras, pero no para caballos», o sea abrupta. 
riqueza ni siquiera las menudas cosas como la casa o las personas queridas. En el fondo lo que busca es recuperar un vivir integrado en el entorno, la seguridad del ambiente familiar, la paz de espíritu. Viene rebotado de esta otra vida escindida por dudas, peleas, sufrimientos, compromisos, arrepentimientos, necesidad de optar y de tomar decisiones por uno mismo.

Cuando el platónico invita al retorno no deja de responder a la misma nostalgia, sólo que él, más radical, traslada — si se prefiere, eleva - ese anhelo a un plano o nivel metafísico, al ser profundo de la persona y a aquello profundo de la realidad que le pueda colmar su anhelo. El platónico diría que no basta con volver a los lugares de la infancia, porque allí acabarán reproduciéndose la retahíla de males que le llevaron a volver. Los males de esta vida provienen de una causa metafísica (la contingencia, la degradación) y solamente lo metafísico es capaz de anularlos.

Un literato puede quedarse en describir las miserias de la condición humana. Un «progresista» hará propuestas para mejorar la situación. El platónico lleva todo eso a un plano radical al ser mismo. Es de la opinión de que el yo es punto de inflexión y de recuperación de la felicidad anhelada. Es retornando como alcanzará el progreso moral ${ }^{4}$ y la felicidad que lo exterior no es capaz de darle. En este caso, el retorno no es para detenerse en el sujeto, porque éste también duda, cambia, etc. La exhortación va dirigida al ser metafísico que subyace a la persona y el regreso a que incitan es a encontrarse con la plenitud, con 'lo absolutamente' (con lo Bueno de lo que participan las bondades sueltas, con lo Bello que es la razón de las bellezas particulares, etc).

En definitiva, tanto Ulises como el «hombre interior» de Plotino o de Agustín anhelan lo integrado, lo anterior a las escisiones y conflictos, lo seguro. A veces, usando el vocablo «al poco más o menos», se ha dicho que Ulises o la Odisea son «la metáfora» del viajero nostálgico de su patria. Hablando con propiedad habría que decir que son el símbolo o el prototipo. Metáfora se hace solamente mientras se llame a otro «el Ulises» de tal época o lugar.

Hay, sin embargo, dos diferencias. Primera: Ulises es el hombre social, que busca la satisfacción en esta vida y en determinado lugar marcado. El personaje de Plotino y Agustín es el hombre interior que busca la satisfacción allende el ámbito social, dentro de su alma, en su conciencia. Segunda: los platónicos no describen un itinerario simbólico, sino un viaje iniciático. Ellos se refieren a lo metafísico de la persona real y y describen lo que consideran el orden correcto de la Razón o, según ellos prefieren decir, la «Via de la Verdad» (Parménides). No sabemos cuantos practicaron el itinerario espiritual de Platón-Plotino, pero sí sabemos de muchos religiosos que practicaron el de San Agustín. Este se limita a estilizar, describir e incitar a una praxis psicagógica conocida.

\section{EL VIAJE INICIÁTICO: EL RETORNO SEGÚN LOS PLATÓNICOS}

La doctrina de Plotino en cuanto tema erudito ha sido expuesta con detalle y a menudo en monografías y libros de Historia. Aquí interesa cómo está construida a juzgar por el vocabulario empleado y cómo a través del elemento metafórico subyacente cabe vislumbrar con qué experiencias cotidianas va coherente. En lo que sigue se repetirán cosas sabidas, pero subrayando literalidades que habitualmente se pasan por alto.

Muchos han incitado a ser mejores, a perfeccionarse, etc, incitando a establecer un futuro más rico en posibilidades de éxito: así todos los «progresistas». Como corresponde a filósofos exterioristas piensan en lograr instrumentos técnicos más eficaces, mejor salud, más placeres y más seguridad de disfrutarlos. Se refieren al individuo en sociedad o, mejor dicho, a la sociedad. Lo que singulariza a los platónicos es que, para ellos, 
1) el progreso es mental y, de resultas, moral. Atañe al individuo en su intimidad personal.

2) el ser metafísico de la persona individual se injerta en el Ser «Fontal»del que es proceso.

2) lo Mejor quedó atrás, en el origen, el proceso natural es de decadencia y, si se quiere mejorar, es preciso retornar (reditio) voluntariamente

3) el hombre, la persona, está en el punto medio de un proceso cósmico y es el punto de reversión.

Platón fue quien sentó las bases de esta doctrina, en parte asumiendo propuestas del orfismo y las religiones de los Misterios. Según el Fedón y según el mito o alegoría de la Caverna, la solución reside en ascender (anagein, Rep. 517 a 5; 521 c 2; 533 d 2) desde lo mundano empírico a lo Pleno (el Bien) del que participa. En el Mito de la caverna se habla de subir, no de regresar. Aunque al cabo resulten equivalentes, serán Plotino y Agustín de Hipona quienes, sin dejar de mencionar la ascensión, acentúan más lo de regresar.

Estos autores se ocupan acerca de algo que está allende lo histórico, lo sociológico y lo biográfico. Se refieren a «el hombre» a nivel metafísico, a la naturaleza de la mente humana común por debajo de diferencias. Por lo tanto algo que nos afecta a todos. En ellos la metáfora del retorno se corresponde con un comportamiento mental que traerá consecuencias en la praxis. No es el caso del tipo introvertido de Jung: la persona reflexiva, que vive hacia sí y medita todo lo exterior, pero sin trascenderse a si misma.

Plotino subsume el tipo introvertido en una doctrina sistemática y con nomenclatura técnica. El se refiere a lo que nosotros (no él) llamamos Realidad o Ser, el conjunto de lo que hay. El Uno es una energía que se despliega (proodós, processio) y se repliega (epistrophé, reditio).

Darwin llegó a la hipótesis del evolucionismo a partir de observaciones hechas en el viaje del Beagle. Para su propuesta de emanatismo, a Plotino le bastaron experiencias cotidianas. Para la fase expansiva menciona la generosidad del magnánimo (bonum diffusivum sui), la imagen de la fuente que desborda, y la savia del árbol que desde las raíces asciende a las ramas. La imagen de la luz que se va obscureciendo es otra metáfora, que comparte con todos los platónicos.

Pero hay otra poco advertida: la procesión cortesana. Los contemporáneos de Plotino podían entender bien la escena porque todavía estaba en pie el Imperio Persa que impuso un protocolo mayestático a su corte, recogido más tarde por los cortesanos del Imperio Bizantino y que subsiste en las procesiones religiosas cristianas. «Así delante del Gran Rey avanza su corte, en vanguardia los personajes menores, seguidamente los hombres de dignidad más elevada; más atrás los familiares al rey, detrás los que desempeñan las más elevadas dignidades y, por fin, aparece el Gran Rey y los asistentes le ruegan y le adoran (Enn.V, 5, 3). En coherencia con esta imagen, el despliegue es de autoridad y dignidad en disminución porque la materia, los cuerpos diversos, los egoísmos, generan multiplicidad y luchas.

Como platónico que es, Plotino es particularmente sensible a los males de esta vida, a la enfermedad y muerte del cuerpo, a las disensiones y luchas, a que los placeres al cabo traen más dolores, etc. Para él se debe a que el proceso de la historia es una decadencia, literalmente una de-gradación, del Bien, que está en la cima y «al principio». Ahora bien, situada a medio camino, la mente humana tiene la facultad, si quiere, de dar la vuelta e invertir la marcha hacia

5 Platón lo adjetiva de eikón, o sea algo así como representación, símil. Que sea alegoría o mito depende de la interpretación. Desde luego desborda de lo que se entiende por alegoría (como la de la línea al final del libro VI), ya que incluye elementos afectivos, axiológicos, como arriba/abajo, luz versus oscuridad. Me he ocupado del tema en mi trabajo «Relectura icónica del mito de la caverna», contribución al libro En torno a Aristóteles, pp.385-402. Servicio de Publicaciones de la Universidad de Santiago, 1988. 
lo que une. Por éxtasis, podría llegar incluso a alcanzar el Uno, pero bueno es ya si alcanza a conocer y amar lo ideal. Pasemos, pues, al retorno ascendente.

\section{Los destinados a la ascensión} I, 3) ${ }^{6}$.

«He aquí los destinados a la subida: el filósofo nato, el músico y el enamoradizo» (Enn.

De la escalera por donde debía dirigir su atención el filósofo nato, es decir, el dialéctico, ya había tratado Platón en el libro VII de la República, y de la escala para el enamoradizo en la conclusión del Banquete. En esos puntos Plotino se limita a repetir. Lo relativamente nuevo (aunque no sin precedentes en Platón) que añade el neoplatónico es proponer al mismo nivel otra escalera, una tercera, a partir de la música.

Por música los antiguos entendían a veces en general lo que nosotros llamamos la cultura y contraponían música versus gimnasia. Cuando tomaban la palabra en nuestra acepción, por música no entendían el arte de combinar sonidos para obtener placer, sino la armonía, la matemática de los sonidos. Por eso la hacían figurar entre las «artes» liberales, en el cuatrivio, formando conjunto con la aritmética, la geometría y la astronomía. Los estoicos, en particular, habían puesto como razón del arte, la proporción, la armonía. Plotino esboza un itinerario que completa los mencionados de Platón.

(Al músico) hay que conducirlo más allá de estos sonidos, ritmos y figuras sensibles del siguiente modo: prescindiendo de la materia de las cosas en que se realizan las "proporciones» y las «razones», hay que conducirlo a la belleza venida sobre ellas e instruirle de que è objeto de su embeleso era aquella Armonía inteligible y aquella Belleza presente en ellas (Enn. I, 3,).

A principios del siglo XVI, el también neoplatónico León Hebreo repetiría el rechazo a reducir la belleza a proporción. Naturalmente, dentro de la costumbre de entonces, remitiendo a Platón y no a Plotino ${ }^{7}$.

\section{La memoria sapiencial}

Nuestra cultura filosófica moderna viene determinada más bien por la antropología de Aristóteles, que es dualista y por pisos superpuestos. Abajo, lo vegetativo, en el medio lo sensorial o sensible; arriba lo inteligible. En los dos pisos superiores, hay lo cognitivo y lo tendencial (apetito). Los platónicos, por su parte, tenían una antropología ternaria recogida en esa tríada que durante siglos se llamó memoria, entendimiento y voluntad. Esta entró en la cultura general probablemente a través del catecismo ${ }^{8}$.

Entendimiento y voluntad se corresponden aproximadamente con lo cognitivo y lo apetitivo (tendencial) de la psicología aristotélica. Si los platónicos abren otro espacio para la memoria y la ponen en el mismo rango, se débe a que por memoria no designan solamente la facultad de recordar tales o cuales acontecimientos puntuales del pretérito. A veces se recuerda lo que nos hizo daño sin quererlo y hasta contra nuestro querer. «Ningún dolor mayor que re-

6 Ennéadas I-II, pág. 225. Biblitoteca Clásica Gredos. Trad. Jesús Igaz.

7 Puede verse mi trabajo «León, el hebreo del Renacimiento», incluido en el volumen colectivo Filosofía y ciencia en el Renacimiento. (Servicio de Publicaciones de la Universidad de Santiago, 1988, pp. 231-260)

8 Me refiero al catecismo del Padre Astete, que durante siglos los niños aprendieron en la catequesis. De ahí es de suponer le viniese a Camilo José Cela el título «Memorias, entendimientos y voluntades» que puso a un tomo de Memorias. 
cordar los tiempos de bonanza en tiempos de desgracia», dejó escrito Dante. Por el contrario, cuando se añora algo, se hace por recordarlo y gozarse en el recuerdo.

Esa es la memoria de hechos, pero hay otra: la memoria de sí. ¿No lo observamos cuando alguien que se ha desmayado «vuelve en sí»? Ahora recuerda quien inserta lo que acaba de ocurrirle dentro de lo que le había ocurrido antes y en la secuencia de su persona.

En el Menón, Sócrates, con preguntas hábiles, consigue que un esclavo enuncie nociones matemáticas no aprendídas (ideas innatas) y si no le llegaron de fuera por aprendizaje, es que las sabía, aunque sin tenerlas presentes y, de pronto, las recuerda. Lo paralelo ocurriría con los primeros principios de la moral. Recordar equivaldría, por tanto, a regresar a estratos de la psique que están antes de los hechos porque afectan a los «primeros principios». Hay, pues, también una memoria sapiencial.

Las prácticas del interiorizar y las del recordar se parecen. También el que se propone recordar algo que tiene olvidado deberá ensimismarse, substraerse a preocupaciones, y hasta cerrar los ojos a cuanto le distraiga de concentrar la atención en los materiales pnemónicos.

Que el recuerdo también salve tiene sentido si ese recuerdo alcanza hasta el origen, tanto de la especie como del individuo, cuando el alma era pura, análoga de la divinidad, y no rota como más tarde por deseos incompatibles, riesgos, tentaciones, dudas. Platón citará con gusto a los órficos que sembraron la tesis de que el ser humano desciende de lo divino (emoi genos ouranion), y que debemos hacer honor a nuestra progenie. Pecando, pensando solamente en lo inmediato, literalmente degeneramos, perdemos género y progenie. Quien conoce el bien, lo cumple, hace Platón decir a Sócrates. ¿Por qué, entonces, se obra tantas veces mal? En la tradición bíblica la Humanidad comienza en el Paraíso y degenera por el pecado original o pecado de la especie en el origen. En la doctrina platónica la respuesta viene en el Fedón cuando se afirma que nuestra alma está borracha, dormida, sumida en sopor de lo sensorial (anima sopita) y «ama su cárcel» (Fedón $79 \mathrm{c}, \mathrm{y}$ passim)

\section{La reditio según San Agustín}

Plotino era un metafísico que habla en tercera persona, acerca del hombre, de su ser metafísico, tal como podía hablar de los astros. Agustín de Tagaste es en las Confesiones un autobiógrafo, alguien que extrae la doctrina de sus propias vivencias, y también un guía (apóstol) comprometido a exhortar y convencer a otros de seguir su camino.

Cualquiera que se hace consciente de la vaciedad (para el sujeto) de los conocimientos meramente informativos y de los placeres «sobre la marcha» se pondrá a reflexionar. Lo característico de Agustín y que lo diferencia de los platónicos laicos es una connotación enérgicamente religiosa hacia Dios entendido como persona, como un $t u$ a quien amar, con quien hablar y demás. En las Confesiones, Agustín inicia y da el modelo para el tipo de escrito que podemos denominar itinerarium mentis ad Deum y que tantas réplicas tendrá en el Medievo.

Igual que en el caso de Plotino no es del caso volver a repasar e hilar textos a fin de presentar una vez más el tema de la interiorización ${ }^{9}$. Lo que aquí importa es el cuadro de sentido dentro del que vienen sus tesis. El proceso de reflexión que propone, lo monta dentro del cuadro de sentido o primordio de salir, volver, concentrarse, todo lo cual implica traducir un proceso moral, de dirección de la mente y de sentimientos, a términos de movimiento local...

Noli foras ire. in te ipsum redi: In interiori homine habitat veritas: et si animam mutabilem inveneris trascende te ipsum (De vera religione, 39,72).

9 De la inmensa bibliografía sobre SanAgustin, remito a Portalié (en la voz pertinente del Diccionario Vacant) y a los textos recogidos por E.Przywara en San Agustín, segunda parte, cap.I. Revista de Occidente Argentina. Buenos Aires, 1949 , 
(No salgas fuera, vuelve a ti mismo: la verdad está en el hombre interior; y si encuentras que el alma es mudable, trasciéndete a ti mismo).

Tal programa presupone una determinada red de sentido y topografía anímica. Por parte del cognoscendum, advertimos que hay un dentro (homo interior) y un fuera (foras), y un viaje que puede, y debe, completarse en sentido inverso. Por parte del cognoscens (autor y receptor) está explícito el sujeto pensador, pero falta un elemento.¿En qué se apoya Agustín para permitirse emplear el imperativo e intimarnos (noli, redi)? Dará como razón que eso es la verdad, lo debido, etc, pero eso lo advertirá la sana razón (le llame así o no). La Razón previene contra la tendencia espontánea a volcarse en la exterioridad (noli foras...) y, si ello ha ocurrido, incita a regresar al interior (in te ipsum redi) porque es ahí donde reside la verdad y en la verdad se descansa (quies).

Agustín es hombre de sentimientos, no un hombre de ciencia. A la polimathía, al enciclopedismo a lo Aristóteles los tiene por curiositas vana. También para él, como supongamos para Aristóteles, lo sensible es el ineludible punto de partida de cualquier reflexión porque la mente está alojada en lo corpóreo, pero en su caso la reflexión conducirá a abandonarlo, ya que no da la felicidad y disipa hacia una curiosidad interminable que no sacia. Lo correcto será, en consecuencia, iniciar la reditio (la epistrophé de Plotino, el retorno) al sí mismo (al te ipsum, al homo interior), pero no simplemente para hacerse más reflexivo, más egocéntrico, más consciente. El sujeto sentencia acerca de lo que es verdadero/falso, él es quien proclama la verdad, pero lo verdadero no lo es porque el sujeto la proclame, ya que la mente humana es mudable y por tanto falible, sino porque aquello valga absoluta y eternamente. El alma, el yo, sufre dúdas, varía, etc. Luego el sujeto ya reconcentrado deberá seguir indagando, es decir, trascendiéndose a sí mismo hasta llegar a algo evidente por sí mismo donde toda duda termine. Por este camino llega a Dios, fundamento de toda verdad y por cuya iluminación él conoce las verdades. Deus intimior intimo meo. Prosiguiendo este proceso, se iría hacia contraponer el amor sui al amor Dei».

Con esta metáfora del itinerario a partir de las dudas y los errores va coherente otro que arranca de las frustraciones de nuestra parte apetitiva. Vivimos en permanente inquietud por las riquezas, por el amor, por los placeres, que, al no satisfacer el ansia, la aumentan todavía más. El inquieto no duerme, no goza, comido como está por las ansias. Pues bien, añade Agustín, la plenitud donde el alma se aquieta y descansará gozosamente. quedó atrás. Solamente algo que sea totalmente bueno, bello, amable, etc saciará toda inquietud. Y de nuevo llega a escena Dios. Inquietum est cor nostrum donec requiescat in te. Y, por eso, Agustin se dolerá de haberlo conocido tan tarde. Sero te cognovi, «tarde te he conocido».

Plotino trataba acerca de lo Absoluto (denominado por él el Uno, el Bien); Agustin trata personalmente con Dios ${ }^{10}$. Dios es para él un tu en la oración y «en la presencia de Dios». El pasa muchas horas en oración con Dios y entonces se ha sentido feliz. Mediante esta experiencia personal Dios, el infinito, el inescrutable, el misterio insondable queda enlazado con lo nuestro cotidiano. Es lo único que sacia y cura del hastío del perderse en curiosidades que nunca concluyen y en placeres que dejan al bebedor más sediento todavía.

\section{Tras el retorno la paz}

Un movimiento concluye cuando se ha conseguido el objetivo, la meta.

Ulises ha regresado a Itaca y tras vencer a los pretendientes de Penélope, descansa con lo suyo, lo de antaño y de siempre: con su esposa, su padre Laertes, su hijo Telémaco, «su tie-

10 En las Confesiones dirá que en los libros de Plotino echaba en falta el carácter personal, el tratar a Dios como un tu que nos habla y al que rezar. Fue lo que le llevó del platonismo a la religión cristiana. 
rra». Y el poema termina, porque se supone que la historia ha concluido. Lo que después ocurriese no interesa. Como dice el ritornello de los cuentos populares, «fueron felices y comieron perdices» y ya se sabe que «los pueblos felices no tienen historia».

El platónico que ha vislumbrado las Ideas, el religioso que se ha encontrado con Dios, sé describe a sí mismo, aunque sea imaginativamente, también en gozo inextinguible:

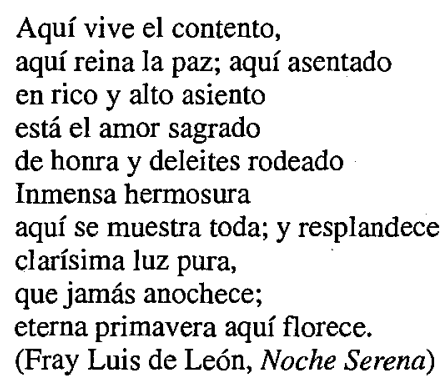

Notemos los detalles que especifica. Sentimientos: paz, amor sagrado rodeado de honra y deleites ${ }^{11}$. Dones físicos: luz, día sin noche, eterna primavera.

\section{La topografia anímica de Ser y Tiempo}

El texto de Ser y. Tiempo permite observar un cierto paralelo con la reditio, sólo que en laico y en hueco.

El Ser-ahí (Dasein), o sea la persona se nos aparece pudiendo estar en uno de dos estados posibles: el estado impropio y el estado propio. En estado impropio el Ser-ahí se nos muestra caído, yecto, perdido en el estado de man (se, uno) es decir,del se diría y uno diría que, disipado en las habladurias. Pero la Conciencia Moral (Gewissen) voca, llama (Ruf) al Dasein a descubrirse como yo mismo y ser auténtico, que, por lo visto, es el estado propio (el que le es propio).

Pero ¿por qué el del que ha salido de la disipación es el estado propio? ¿En base a qué voca la Conciencia a salir de la inautenticidad, las habladurías y demás? Cuando describe el estado de caído, Heidegger se aproxima a la descripción que Agustín hace de la disipación e incluso llega a citar las Confesiones (Ser y Tiempo, parágrafo 36) apropósito de la concupiscencia. Sin embargo, al cabo evita toda invitación moralizante y religiosa, con advertencias de este tipo:

«La exégesis ontológico-existenciaria tampoco hace, por ende, afirmaciones onticas sobre la «corrupción de la naturaleza humana», no porque falten los indispensables medios demostrativos, sino porque sus problemas son anteriores a toda afirmación sobre corrupción e inocencia. La caída es el concepto ontológico de un movimiento» ${ }^{12}$.

Heidegger quiere mantenerse en fenomenólogo que se ocupa de lo formal donde se alojarán los contenidos (positivos/negativos). Un descompromiso no muy distinto del que aquí hemos hecho al traer la cuestión a la infraestructura metafórica de la doctrina.

11 El contraste del «amor sagrado» con el «amor profano» fue un tópico de la época renacentista y aparece en cuadros famosos.

12 Ser y Tiempo, 38. Trad. Gaos.En la edición de 1952 que manejo es la página 207. 


\section{LA NOSTALGIA DE LOS ORÍGENES}

A menudo se ha descrito el tipo del anciano de vuelta de la atolondrada y extrovertida juventud, que se propone ser más reflexivo, rumiar las peripecias de la vida, centrarse más en sí mismo.. Con Plotino y Agustín tenemos delante una doctrina cosmovisional que exhorta a una actitud y unos procedimientos morales y psicagógicos (de conducción de la mente) para liberar al yo de la dispersión en lo exterior y concentrarle en lo íntimo porque la verdad -y lo «de verdad»- habita, tiene su morada, en el interior. El camino conduce a anular la individualidad partida y reingresar en la unidad. En Plotino, mediante la contemplación y en San Agustín mediante la oración.

Hemos detectado que la doctrina de la reditio se inscribe dentro de la «figura» de la nostalgia de los orígenes, cuyo símbolo y arquetipo es Ulises, pero el viaje de los platónicos es un viaje iniciático. Su biógrafo Porfirio testifica que Plotino alcanzó el éxtasis tres. veces en su vida.

La Odisea narra una ficción simbólica: la doctrina platónico-agustiniana presenta un programa de dirección de la mente (psicagogia).

A la ficción de Homero no se le pide sino verosimilitud y capacidad simbólica para casos reales. Quienes leen y exponen la doctrina platónico-agustiniana se limitan a enterarse sin tomar partido y, si no son creyentes religiosos, tal vez opinen que ese proceso es una ilusión de la psicología metafísico-religiosa.

En todo caso el análisis formal muestra que, a pesar de las diferencias, en la ficción y en la doctrina programática se «anda» el mimo proceso, es decir, retroceder desde la dispersión insatisfactoria a lo unitario, integrador y satisfactorio (dador de felicidad)

\section{LA METÁFORA SUBYACENTE}

Llega ahora el momento de abordar los compromisos de lenguaje subyacentes a la doctrina.

Ulises vuelve espacialmente, geográficamente, pero ¿con qué «derecho» se permiten Plotino y Agustín eso de regresar a lo interior si ahí no hay espacios ni distancias? ¿Con qué razón de aquello que solamente yo sé y podría guardar para siempre en secreto digo que lo guardo en mi interior y lo califico de íntimo, superlativo de intus? ¿Con qué razón a la acción de hacerse uno mejor moralmente se la describe como regresar adentro, a sí mismo? Eso implica asimilar un proceso moral ajeno al espacio a un movimiento local. Ahí está funcionando crípticamente la metáfora de expresar en términos espaciales lo que por naturaleza no es espacial. El mejorar moral pertenece al ámbito de valores y sentimientos, ¿cómo se justifica que se lo exprese en términos «cinemáticos», de movimiento local (ir, volver, marchar, regresar)?

Todos habremos contemplado alguna variante del siguiente hecho de la vida cotidiana: un mecanismo tenso - un arco, un brazo- sale desde su lugar o cubículo al exterior y, conforme se va extendiendo pierde tensión. En un momento siguiente, alguien lo fuerza a movimiento inverso, contrae las energías disipadas, las concentra y retorna al estado inicial tenso, que por lo visto es el natural, el correcto.

O bien: alguien sale muy animado de su casa hacia un lugar que le ilusiona, pero llegado al término deseado del viaje, se siente defraudado y entonces suspira por recuperar el punto de partida y se pone regresar.

Hasta aquí, hechos físicos

Sea ahora una vivencia, también de la vida cotidiana, que por vivencia es inmaterial. Nuestra alma o yo o mente, como quiera decirse, está volcada hacia lo exterior, hacia lo otro, sea para conocerlo, sea porque le apetece, es decir, porque siente apetito de ello. Los escolásticos y la fenomenología lo expresan diciendo que «tiene intencionalidad» (Husserl). El tipo extro- 
vertido lleva esto a grado extremo. Sea un sujeto descontrolado como esos individuos de los que decimos que llevan una vida disoluta, disipada. Estando su atención solicitada por tantas cosas, irá de una cosa en otra, sin entrar a fondo en ninguna, prisionero del «afán de novedades». Charlará de todo, pero sin decir nada «de substancia», porque tiene «la cabeza a pájaros». Supongamos que llega un momento en que siente ese modo de vida como vacío, ya no le satisface andar de aquí para allá, siente hastío, y, entonces se pone a retornar a sí mismo, a volver a ser él mismo, a ser un sujeto que se autocontrola y es señor de sí y no una veleta movida por todos los vientos.

¿Ha reparado el lector que esta segunda descripción que lo es de «cosa» inmaterial está hecha con muchas de las mismas palabras que la anterior? Ahora bien, ¿con qué «derecho» expresamos estas vivencias inmateriales mediante vocabulario físico, en concreto, mediante una metáfora cinemática? No siendo, la mente, cosa material, no ocupa lugar y, por lo tanto, ni sale ni retorna.

«Una de tantas metáforas», puede decir un precipitado, más para salir del paso más que para dar una respuesta: «asunto de ornato literario porque lo mismo podría ser dicho sin ellas». Pues bien, esto es lo que no ocurre: nadie conseguirá describir esa red de vivencias sin introducir referencias al espacio y al movimiento local. Esta de que trato no es la metáfora que un literato crea y otro puede evitar; es una de las metáforas que ya viene en el lenguaje común. Refirámonos ahora a los textos de Plotino y San Agustín. Si eliminásemos expresiones como vuelta a si mismo (epistrophé, reditio), exterior/interior y demás sus textos quedarían sin sentido.

Nosotros recibimos el lenguaje como si fuera una baraja con cartas - las palabras - que está en nuestro poder combinar como queramos, pero el problema quedó antes, atrás. El lenguaje fue inventado alguna vez y está todavía siendo inventado ahora mismo en alguna mínima parte. Pues bien, ¿qué «operaciones» ocurren en los sótanos de nuestra mente para que dos fenómenos tan heterogéneos como los citados resulten ensamblados en dos series que se corresponden? Evidentemente, el usuario (el hablante) no sabe las razones. Sin embargo,alguien lo habrá hecho en lugar de él, ese que llaman el Subconsciente y que yo prefiero denominar. Cisconsciente

En estos casos, siempre hay alguna palabra relevante del lenguaje ejercido que es indicio y hace posible reconstruir el conjunto de sentido, supliendo lo implícito conforme a la coherencia de sentido. En el caso presente esa palabra estratégica, el indicio de toda la constelación, es regreso (reditio). Retornar, regresar, implica un marco semántico o cuadro de sentido que incluye espacio, dentro/fuera, movimientos de ida y vuelta, disolución en lo exterior, interiorización, etc.

\section{Topografía del alma}

Desde esos movimientos volvamos a lo que implican para el sujeto o, como se decía tradicionalmente, el alma ${ }^{13}$. Por lo visto, el sujeto es un espacio heterogéneo con un centro y una demarcación entre lo interior y lo externo. Por otros indicios tenemos derecho a pensar que sea un círculo y por tal incluirá

- centro

- circunferencia

- periferia.

13 Sócrates exhortaba al «cuidado del alma» (epiméleia thes psiches). Todavía Descartes que ya admite en su terminología el yo, incluso en las Meditaciones y otros lugares donde habla en primera persona mantiene el alma como sujeto del yo. 
Solamente así tiene sentido que haya viaje de salida y de vuelta. Salir lleva a disiparse en lo exterior: volver lleva a concentrarse en el interior. Con una diferencia: salir se hace espontáneamente, no requiere siquiera hacer nada, basta con dejarse llevar. En cambio, volver requiere esfuerzo.

Lo cual implica, a su vez, que nuestra alma (conjunto de disposiciones del sujeto) trae un desarreglo de naturaleza, un fallo de origen: tiende hacia lo exterior que nos acabará defraudando. Ahora bien, por fortuna dispone también de un poder hegemónico - la razón, se la mencione o no- para ordenar el regreso hacia una situación correctora del fallo e instalarse en lo correcto. O sea, volver de lo impropio a lo propio (en la acepción de «lo propiamente dicho»).

Por lo tanto, la voz natural es ambigua. Puede significar lo espontáneo, lo que se hace sin esfuerzo, y puede significar lo propio de algo, lo correcto y adecuado, lo debido, que se recupera por decisión y esfuerzo.

Interior/Exterior es también una demarcación en referencia a nuestro cuerpo o soma. La percepción presenta nuestro cuerpo en cuanto contrapuesto al entorno o lugar donde se está. Este es el significado originario de soma en griego ${ }^{14}$. Hay sensorios propioceptores («cenestésicos», de dolor, de calor/frío, etc) y exteroceptores (los conocidos «cinco sentidos»). Al yo lo percibimos como situado vagamente entre la cabeza y una línea que pasa por debajo del corazón.Sin duda, también las piernas son nuestras, pero evidentemente. en caso de apuro, las entregaríamos para salvar ese otro sector somático que sabemos condición inmprescindible para vivir.

Una determinada zona del cuerpo se veda al público, no se permite ver ni tocar. Solamente se dona como regalo a aquel o aquella persona con la que se tienen «relaciones íntimas» ${ }^{15}$.. También en la casa demarcamos una zona abierta a los demás y una zona privada. En muchos negocios abiertos al público puede verse sobre alguna puerta el letrero: «Privado».

Obviamente esta intimidad, del cuerpo o del domicilio familiar, no se identifica con aquella de que se trata cuando de hablamos de «retornar» a sí mismo, pero convenía mencionarla porque ambas se refuezan recíprocamente.

\section{Un dilema}

Hemos detectado asimismo que es ineludible expresar ese viaje mental en términos de movimientos espaciales. según dos posibilidades: la de estado ỳ la de movimiento. La de estado, cuando se habla de dentro/fuera para lo que no ocupa lugar, lo que implica meter lo anímico, lo mental, en topografía. La de movimiento, cuando se exhorta a regresar al hombre interior, lo que implica expresar los actos mentales en términos de andar y moverse localmente. Ahora bien, no siendo material, ¿no es contradictorio decir de la mente que sigue un camino, se desvía, regresa? Por su parte, Dios es un elemento metafísico, que está allende lo empírico, invisible, inalcanzable por ninguna bușca comprobable. ¿Cómo puede afirmarse que esté dentro del yo?

Esto fuerza a revisar ese lugar común según el cual la metáfora es en todos los casos una expresión inexacta que podría ser substituida por un decir más preciso.

Para la Ciencia y para la Ontología de esencias (valga la redundancia) la metáfora es un escándalo. Frente a él cabe asumirlo o zafarse.

Lo habitual es lo segundo, zafarse, alegando que se trata de una simple analogía per extrinsecam denominationem y alegando que es cosa meramente de la expresión que, según se

14 Bruno Snell: Las fuentes del pensamiento europeo. (Madrid, Edit. Razón y Fe, 1965). Ver en particular el capítulo «Concepción homérica del hombre»

15 Se sabe que no todos los pueblos han fijado como zona íntima los genitales, pero es de suponer que incluso entre las tribus desnudas el individuo demarcará una zona reservada de su cuerpo 
dice, puede ser superada mediante expresiones técnicas más rigurosas. Ahora bien, eso no siempre ocurre. Imposible suplir mediante expresiones técnicas eso de proceso interior, regresar al yo íntimo, etc. Esos supuestos términos no metafóricos que se pongan en su lugar seguirían siendo metáforas, sólo que antiguas y de cuya metaforicidad se ha perdido la conciencia por la habituación.

Asumamos el escándalo y constataremos que no lo es. Nos escandalizan las metáforas porque la tradición y la educación nos instalan en un mundo de «entes» a definir por ciertos rasgos. Así considerada la Realidad se nos presenta fraccionada en géneros, especies, tipos, clases, etc hasta llegar al «individuo inefable» y la pretensión del conocimiento es identificar cada esencia y diferenciarla de otras. En correspondencia con ello tradicionalmente sólo se admite como poder mental la inteligencia que, según los casos, «intuye» esencias (intellectus), y discurre (razon, dianoia). A su vez, esos entes vienen dados en campos diversos (lo mental, lo físico, lo psicológico, etc.)

Ciertamente desde tal enfoque por entes según géneros y especies las metáforas han de resultar una anomalía inexplicable y que todo lo estropea ya que hacen las coyundas más prohibidas, como esto de decir con términos físicos lo que no es físico, tomar la atención como si fuese algo que se estira, que se concentra, etc. No ha de sorprender que, al encontrarse con las metáforas y englobarlas dentro de la analogía del ser, las calificasen los escolásticos de analogía per extrinsecam denominationem. (De acuerdo, pero si se diferencian de las falsedades, por algún fundamento será)

Ese es el modo de considerar las cosas que practicamos todos en la vida diaria y la base de la ciencia, y por supuesto nadie va a negarle validez. Otra cosa es si es el único procedimiento de ordenar el Mundo. Admitamos hipotéticamente dos supuestos. No solamente hay entes «por sí», sino también cosas-sentido y hechos que son cuadros de sentido, y no solamente por causalidad y finalidad. También ordenamos el Mundo según semejanza y hay semejanzas que trascienden y desbordan los enrejados ontológicos.

Razonando así, no se solucionan los «problemas»: se disuelven, dejan de ser problemas para pasar a constataciones.Así, el salir/regresar, exterior/interior, pasan a ser un hecho de sentido que puede cumplirse por igual entre campos tan diversos como lo mental y lo espacial. Consideradas así las cosas la metáfora deja de ser el escándalo que era desde una Ontología de sólo esencias.

\section{Los Primordios}

Volvamos a la pregunta del inicio: ¿por qué para expresar lo inmaterial se requiere emplear términos físicos? A quien minimice el problema alegando que «se trata de una de tantas metáforas» hay que hacerle notar la singularidad. Este no es el caso de «el rey de la selva» dicho en lugar de león ni el de «violines del otoño» dicho en lugar de vientos otoñales ni de rascacielos dicho en lugar de edifício muy alto ${ }^{16}$. Al león y a los vientos y a los altos edificios se los puede describir por si mismos directamente sin metáfora. En cambio en el caso del retorno del alma (o mente) a sí mismo, igual que en otros similares, nos las habemos con expresiones ineludibles: no hay otro modo de expresar esas vivencias que valiéndose de expresiones tomadas al lenguaje espacial: salir-entrar, salir-volver, concentrarse-disiparse. Estamos ante un tipo de metáforas que vienen ya acuñadas en el lenguaje cotidiano y por haberse perdido la conciencia de metaforización han pasado a conceptos.

16 Hoy en rascacielos se ha olvidado la metáfora. Lo tomamos como un nombre más. Sin embargo, revive cuando aprendemos la palabra equivalente en otro idioma: raña-ceos (portugués.). Evidentemente, por alta que sea, una casa no rasca el cielo ni el espacio puede ser arañado. 
A metáforas de este tipo he propuesto en otros lugares denominarles Primordios, organizaciones de sentido dentro de un campo de sentido que posibilitan alojar dentro de ellas contenidos inmateriales. Otras serían subir-bajar, luz-oscuridad, etc ${ }^{17}$.

Quizás en este tipo de metáforas reside el secreto del origen del lenguaje humano y del pensamiento abstracto. La misma expresión es, por el haz, imagen y por el envés concepto.

Cada vez que el lenguaje registra que tal persona que andaba disipada se reencontró a sí mismo, recuperó su concentración, detrás, implícito, va un cuadro de sentido.

Quien vuelve localmente de un lugar, deja de ver ciertas cosas; quien, incluso manteniéndose en el mismo lugar, vuelve la vista ve otro paisaje y quien tuerce su atención de lo mundano contempla vívidamente las ideas plenas, divinas. El sentido es el mismo, se trate de dominar la mirada y volverla sobre sí o se trate de regresar a la tierra natal o de volver a contemplar las ideas que son connaturales a la mente. Es la misma «figura».

Hemos dado con un primordio, una matriz de relaciones de sentido, que permite conectar varias doctrinas que a primera vista, atendiendo a los contenidos, están inconexas.

\section{LA MARCHA DE LA HISTORIA}

Desde la doctrina del in te ipsum redi, una filosofía «mundana», enciclopédica, no pasaría de prolongar la vana curiositas. La línea de pensadores medievales agustinianos así lo entendió y practicó. Claro que eso llevaba como consecuencia implícita renunciar a entender la realidad mundana, dejarla sin explorar, mero hecho bruto, y en los siglos medievales, efectivamente, hubo escaso interés en investigarla. Pero he aquí que «el hombre por naturaleza desea saber» (el contexto del párrafo de Aristóteles aclara que desea ver) y el futuro iba a preferir satisfacer esta curiosidad. De una cosmovisión interiorista a una cosmovisión exteriorista.

En determinado momento de su vida, Petrarca, clérigo en la corte papal, asciende al monte Vendoux, próximo a Avignon ${ }^{18}$. Llevaba en el bolsillo el texto de las Confesiones donde se habla en contra de viajar para ver curiosidades. Sin embargo, lo que hace al alcanzar la cima es ponerse a contemplar el paisaje. Está inaugurando el Renacimiento. Esa mirada al paisaje es un símbolo de la enorme curiosidad del hombre que Oswald Spengler, con su enorme poder para encontrar palabras certeras, denominó «fáustico»: el ansioso por saberlo todo.

La propuesta de interiorización siempre encontró resistencias en el foro individual porque lo espontáneo es extrovertirse, pero del Renacimiento para acá va además a contrapié, a contra-tiempo de cómo marcha de la historia. Nuestra sociedad es cada vez más extrovertida y disipada. Pocos valoran al «virtuoso», al «sabio» y a las «bellas almas», como decían los románticos. Se tiende a medir todo por la eficacia y el éxito público.

Sin embargo, en la historia «nada se pierde, todo se conserva». La doctrina del retorno a sí prosigue ahí como una oferta.

En todo caso, mi tema no ha sido opinar acerca de la doctrina, sino otro que pasa inadvertido desde enfoque doctrinal y que, sin embargo, tiene trascendencia si nos interesamos por saber cómo funcionan nuestro pensar y nuestro lenguaje. Importaba la infraestructura dentro de la cual se aloja esa doctrina que los autores citados llevaron hasta el nivel metafísico-religioso.

Ha quedado al descubierto el primordio con respecto al cual tiene sentido tanto el extrovertirse y disiparse como el regresar al sí mismo.

17 Se corresponden aproximadamente con las metáforas que Lakoff y Johnson denominan metáforas estructurales y orientacionales (Metáforas de la vida cotidiana.Madrid, Cátedra,1986).

18 J. Burkhart: La cultura del Renacimiento en Italia, pág. 222. Barcelona, Edit. Iberia, 1971. 
Un primordio estrechamente emparentado con el del ascender. El platónico que asciende es un alpinista. Como éste, ha de aceptar sacrificios, renunciar a lo menos valioso en favor de lo más valioso aunque sea difícil («lo bello es difícil») y, en fin, tener «moral» deportiva. EI plotiniano y el agustiniano que regresan a sí mismo practican la misma actitud de quien cierra la puerta de su casa para aislarse del entorno y de quien, en algún momento de su vida cierra ojos y oídos, se desentiende de lo foráneo, habla consigo y se escucha a si mismo. Por su parte, el que ansía la paz interior por estar hastiado de las interminables luchas por la vida coincide psicológicamente con el adulto que siente nostalgia de la infancia y del hogar paterno. $\mathrm{Y}$ ambos coinciden aproximadamente con la práctica de quien resuelve recordar algo: también éste se niega a cuanto le distraiga a fin de concentrarse a que reaparezca en su mente aquello olvidado.

Las vivencias son aproximadamente las mismas, se trate de un campo $u$ otro, porque hemos ido a parar a un primordio, una primera ordenación de sentido, una protometáfora ineludible. A través de las metáforas descubrimos los Primordios, porque éstos son los que permiten y dan razón de las metáforas con esa trascendencia y que no se reducen a meros adornos literarios.

Carlos Baliñas Fernández Departamento de Filosofía y Antropología Social

Facultad de Filosofía

Campus Universitario Sur 15782 Santiago de Compostela 